\title{
Influence of filtration and glucose amendment on bacterial growth rate at different tidal conditions in the Minho Estuary River (NW Portugal)
}

\author{
I. Anne ${ }^{1,2}$, M. L. Fidalgo ${ }^{1,2, *}$, L. Thosthrup ${ }^{3}$ and K. Christoffersen ${ }^{3}$ \\ (1) Department of Zoology and Anthropology, Faculty of Sciences, University of Porto, Praça Gomes Teixeira, \\ 4099-002 Porto, Portugal \\ (2) Centre for Marine and Environmental Research (CIIMAR), Rua dos Bragas 289, 4050-123 Porto, Portugal \\ (3) Freshwater Biological Laboratory, University of Copenhagen, Helsingørgade 51, DK-3400 Hillerød, Denmark \\ * Corresponding author: lfidalgo@fc.up.pt
}

\begin{abstract}
Influence of filtration and glucose amendment on bacterial growth rate at different tidal conditions in the Minho Estuary River (NW Portugal)

Bacterioplankton abundance, biomass and growth rates were studied in the Minho Estuary River (NW Portugal). The influence of tidal conditions, glucose amendment, and the filtration process on total bacterial abundance, total and faecal coliforms, as well as faecal streptococci, were evaluated in laboratory incubation experiments. Physical and chemical conditions, as well as bacterial abundance in this estuary were found to be typical for oligo-mesotrophic coastal ecosystems. Bacterial abundance was higher at high tide, probably due to hydrodynamics and resuspension of bacteria from sediments. In contrast, a significant decrease of bacterial indicators of faecal pollution at high tide was probably the result of various causes, such as the decrease of continental and agricultural land run-off effect by dilution, and/or increase in the abundance of potential specific predators. Thus, drastic changes were induced at high tide that led to a lack of bacterial growth and the net disappearance of most of the bacterial populations. Glucose amendment, at used concentration, was not found to stimulate bacterial growth, which instead could be limited by inorganic nutrients.
\end{abstract}

Key words: Bacterioplankton, faecal indicators, filtration, glucose amendment, tides.

\section{RESUMEN}

Influencia de la filtración y de la adición de glucosa en la tasa de crecimiento bacteriano en diferentes condiciones de marea en el estuario del río Miño (Noroeste de Portugal)

La abundancia, la biomasa y las tasas de crecimiento de bacterioplancton fueron estudiadas en el estuario del río Miño (NW Portugal). La influencia de condiciones de marea, de la adición de glucosa y del proceso de filtración en la abundancia total de bacterias, coliformes totales y coliformes fecales, así como de estreptococos fecales, fue evaluada en experimentos de incubación en laboratorio. Las condiciones físicas y químicas, así como la abundancia bacteriana encontradas en este estuario son típicas para los ecosistemas costeros oligo-mesotroficos. La abundancia bacteriana fue más alta en la alta marea, probablemente debido a la hidrodinámica y a la resuspensión de bacterias de los sedimentos. En contraste, la disminución significativa de los indicadores bacterianos de la contaminación fecal en la alta marea resultó probablemente de varias causas, tales como la disminución del efecto de vertido de la región continental y agrícola por la dilución, y/o aumento en la abundancia de depredadores específicos potenciales. En resultado, cambios drásticos fueron inducidos en la alta marea originando la ausencia de crecimiento bacteriano y la desaparición neta de la mayoría de las poblaciones bacterianas. La adición de la glucosa, en la concentración usada, no estimuló el crecimiento bacteriano, que se podría limitar por los alimentos inorgánicos.

Palabras clave: Bacterioplancton, indicadores fecales, filtración, adición de glucosa, mareas. 


\section{INTRODUCTION}

Several environmental factors, such as predation, organic dissolved substrates, toxic compounds, temperature, and solar radiation may influence bacterial growth and survival in the aquatic environment (Sherr et al., 1989; Nybroe et al., 1992; Christoffersen et al., 1995; Hansen \& Christoffersen, 1995; Suzuki, 1999; Caron et al., 2000; Calbet et al., 2001).

In estuarine areas, tides are natural phenomena that cause changes in the densities of bacterial populations and heterotrophic activities (Cunha et al., 2000; 2001). The diversity of the bacterial assemblages may also be affected by the twice-daily rhythm of tides, because the two systems (ocean and estuarine waters) differ in terms of growth conditions and carrying capacity. On the other hand, microbiological pollution represents one of the most widespread impairments for water uses caused by urban drainage discharges. Moreover, concerns about the spreading of waterborne diseases caused by such waters led to the promulgation of bacteriological water quality criteria which specify the tolerable concentrations of various faecal indicator microorganisms. The primary criteria deals with indicator bacteria (e.g. total coliforms, faecal coliforms, faecal streptococci, Escherichia coli) which indicate the potential presence of pathogens (USEPA, 1986; Marsalek et al., 1994).

The study of the relationship between tide events and faecal indicator bacteria in estuarine areas is of great importance, because it allows making useful recommendations in terms of water use and public health protection (Fattal et al., 1986). In this sense, to know the estuarine dynamics of faecal indicator bacteria can represent an important contribution particularly if effluent discharges reach estuarine areas as it occurs in the Minho Estuary River. To our knowledge no previous studies were carried out on this estuary concerning bacterial dynamics, which should encourage additional investigations in order to fill this gap.

The main goals of this study were to determine (i) the relationship between tidal events and abundance of faecal indicator bacteria in the
Minho Estuary River and (ii) the influence of the tidal conditions, filtration and glucose amendment on bacterial abundance and overall growth rate. Aiming to achieve the mentioned goals, a field-sampling programme was designed to characterise the bacterioplankton pool in the Minho estuary at low and high tides. Moreover, estuarine water samples were experimentally manipulated in the laboratory to determine the overall growth rates of bacterioplankton assemblages.

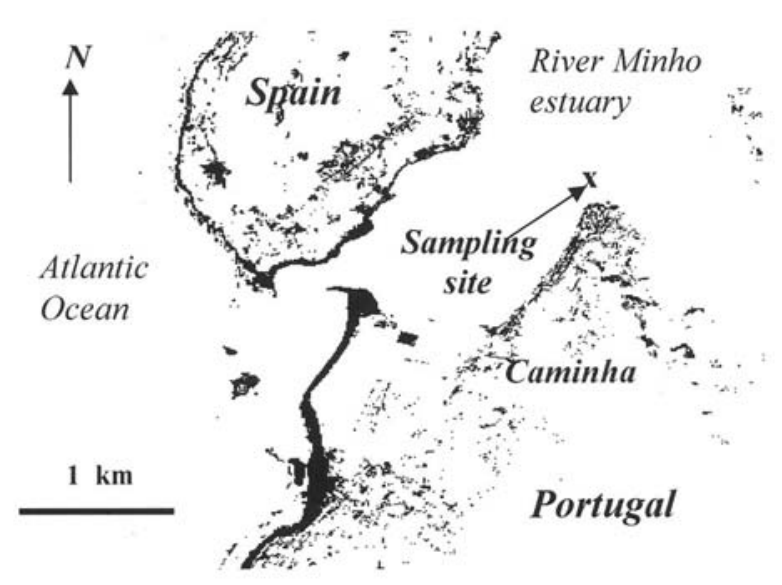

Figure 1. Location of the sampling site in the Minho Estuary River, North West coast of Portugal (Image from the National System of Geographic Information, Portugal). Ubicación del punto de muestreo en el estuario del río Miño, costa Noroeste de Portugal. (Imagen del Sistema Geográfico Nacional, Portugal).

\section{MATERIAL AND METHODS}

\section{Sampling site}

The Minho Estuary River is a temperate water-body located in the North West coast of Portugal $\left(41^{\circ} 52^{\prime} \mathrm{N}, 08^{\circ} 51^{\prime} \mathrm{W}\right)$ (Fig. 1). The sampling site was established on the left bank of the Minho estuary, at the small town of Caminha, approximately $1 \mathrm{~km}$ upstream of the Atlantic Ocean. Water samples were collected in April 1998 (days 22 and 29) during the low and high tide for the physical and chemical characterisation of the estuarine water as well as for the enumeration of bacterial abundance 
and faecal indicator bacteria; on days 22 and 29 , water samples were experimentally manipulated in the laboratory to determine the overall growth rate of bacterioplankton assemblages at low and high tide conditions, respectively.

\section{Physical, chemical and bacteriological variables}

Water temperature, $\mathrm{pH}$, dissolved oxygen, conductivity and salinity were determined in situ using an YSI Model 33 SCT meter and an YSI Model 54 oxygen probe.

Water samples from the bottom (about $1 \mathrm{~m}$ depth and $3.5 \mathrm{~m}$ depth, at low and high tides, respectively) and from the water surface (about $0.1 \mathrm{~m}$ depth) were collected with a 2liter Ruttner sampler and pooled into a composite sample of approximately $30 \mathrm{~L}$. We kept collected water samples in isolated isothermic containers which were transported to the laboratory within a few hours. In the laboratory, we homogenised the water before we measured alkalinity and chlorophyll a (Chl a). We measured alkalinity using the acidimetric indicator end point method (Golterman et al., 1978) and Chl a according to Lorenzen (1967).

The total bacterial number (TBN) was determined by epifluorescence microscopy after fixating water samples with glutaraldehyde ( $1.5 \%$, final concentration). The samples were filtered through black Nuclepore filters $(0.2$ $\mu \mathrm{m}$ pore size), stained with 4', 6-diamidino-2phenylindole (DAPI) $(1 \mu \mathrm{g} / \mathrm{mL}$, final concentration) according to Porter \& Feig (1980); stained filters were mounted on glass slides with Leica immersion oil, and then frozen $\left(-20^{\circ} \mathrm{C}\right)$ until microscopic examination. On each filter, at least 300 cells were counted in 10 fields (x1250 magnification) using a Leica DM LB 30T microscope equipped with a fluorescence filter system (ultraviolet excitation filter of $340-380 \mathrm{~nm}$, and emission filter of $430 \mathrm{~nm}$ ) and a fluotar 100/1.32 oil objective. Cells were measured under an epifluorescent microscope with the aid of an ocular lens equipped with a reticule (Graticules Ltd).

The membrane filtration method included in the APHA procedures (1992) and three dilutions (sterile $\mathrm{NaCl}, 0.9 \%$ ) with three replicates for each dilution were used to count total coliforms (TC), faecal coliforms (FC), and faecal streptococci (FS).

The specific growth rates of the bacterial assemblages in the laboratory experiments were estimated as $k=1 / t \times \ln \left(N_{t} / N_{0}\right)$ (Mcmanus, 1993), where $k$ represents the growth rate, $N_{t}$ the total bacterial number at time $t$, and $N_{0}$ the total bacterial number at time 0 .

Determination of the total bacterial biomass was based on a mean value of cell biovolume of $0.07 \mu \mathrm{m}^{3}$ that was obtained from size measurements of approximately 50 cells by each counted field, and visualised on enlarged micrographs. The calculation was done according to the allometric relationship between cell volume and carbon content reported by Norland (1993).

\section{Experimental setup}

For each tide condition, the experimental setup in the laboratory was as follows: a sub sample was taken from the composite sample obtained in the field and was distributed in twelve cleaned $1.5 \mathrm{~L}$ polycarbonate bottles that were placed in a $15 \mathrm{~L}$ water bath. The water bath was continuously flooded with tap water to keep the samples at $15-17^{\circ} \mathrm{C}$, which was similar to the in situ temperature at the sampling time. One set of six bottles was filled with water screened through a $20 \mu \mathrm{m}$ mesh size net, while another set of six bottles was filled with water sequentially filtered through GF/C filters and then through a $1 \mu \mathrm{m}$ pore size polycarbonate membrane filter. We assumed that the first set of bottles contained the natural density of heterotrophic flagellates and ciliates $(<20 \mu \mathrm{m})$ and we also assumed that the second set did not contain the mentioned predators. All bottles were incubated at room light and each bottle was aerated to create water circulation by means of a tube connected to an air pump; a small piece of cotton was placed in the free tip of the tube to avoid contamination of the culture bottles by airborne bacteria. The bottles were allowed to stand for 2 hours without further manipulation for acclimation before the first sampling. Then, three bottles of each set of 
six bottles were amended each with $1 \mathrm{mg}$ glucose per litre. Thus, each experimental condition was run three times.

The two experiments lasted four days, and sampling was performed every 24 hours, except on the third day for the experiment at high tide condition, because of logistical problems.

To compare the four sets of conditions for each tide condition, we performed a statistical analysis day by day: we used the two-tailed $t$-test to test for differences between means of total bacterial number and number of faecal indicator bacteria at low and high tides; we assessed differences between the average biomass in all laboratory treatments in each experiment by the non-parametric Kruskal-Wallis ANOVA by ranks (Fowler et al., 1998).

\section{RESULTS}

\section{Physical, chemical, and bacteriological variables in the study site}

The basic physical and chemical variables measured in the sampled area are given in Table 1. Water temperature varied between $12.4^{\circ} \mathrm{C}$ and $13.3^{\circ} \mathrm{C}$ at low tide, and between $13.0^{\circ} \mathrm{C}$ and $13.9^{\circ} \mathrm{C}$ at high tide. Estuarine waters were well oxygenated, and $\mathrm{pH}$ ranged from neutral (7.0) to slightly alkaline values (7.9). Measurements of salinity $(0.0$ and $0.3 \%$ ) and conductivity (120 and $280 \mu \mathrm{S} / \mathrm{cm}$ ) clearly reflected the dominance of freshwater during low tide and that of marine oceanic water during high tide $(23.0 \%$ and $29500 \mu \mathrm{S} / \mathrm{cm})$. During high tide, salinity varied

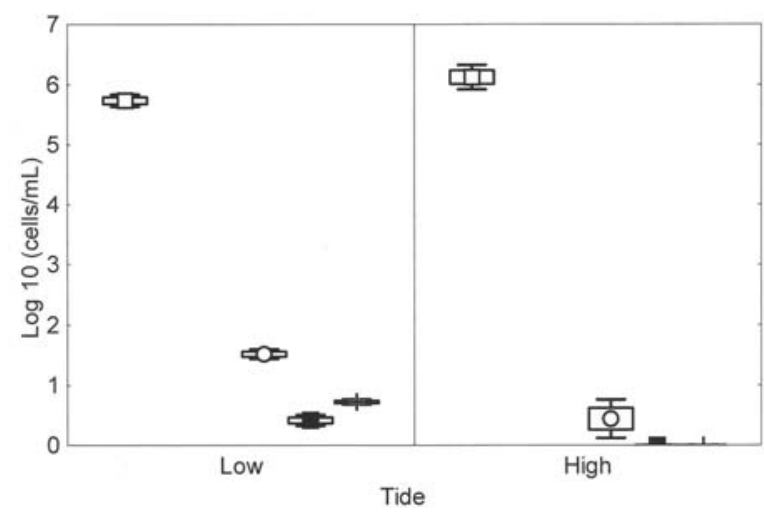

Figure 2. Average field bacterial densities at low and high tides in the Minho Estuary River (Bar and whisker plot; bars: Mean \pm Standard error; whiskers: Mean \pm Standard Deviation; Total Bacterial Number: white rectangle; Total Coliforms: white circle; Faecal Coliforms: black square; Faecal Streptococci: cross). Densidades bacterianas promedio en baja $y$ alta marea en el estuario del río Miño (Barras y figura whisker; barras: Media \pm Error estándar, whiskers: Media \pm Desviación estándar; Número total de bacterias: rectángulo blanco; Coliformes totales: círculo blanco; Coliformes fecales: cuadrado negro; Estreptococos fecales: cruz).

from $3.0 \%$ at the water surface to $25.0 \%$ at the bottom; conductivity varied from $5000 \mu \mathrm{S} / \mathrm{cm}$ (at water surface) to $31000 \mu \mathrm{S} / \mathrm{cm}$ (at the bottom), indicating the existence of a salinity and conductivity gradient in the prospected area. At low tide, there was practically no remaining salinity and the conductivity was much lower comparing with high tide.

This situation is typical for the Minho Estuary River, because Azevedo (1995) reported similar values and confirms that our results were typical for that tidal influenced area. At high tide, alkalinity was higher at both sampling dates, showing

Table 1. Physical and chemical variables of the pooled water samples (covering the entire vertical profile). Variables físicas $y$ químicas promedio de las muestras de agua (agrupando a todo el perfil vertical).

\begin{tabular}{lcccc}
\hline Variables & \multicolumn{2}{c}{ April 22, 1998 } & \multicolumn{2}{c}{ April 29, 1998 } \\
\hline & Low tide & High tide & Low tide & High tide \\
\hline Water temperature $\left({ }^{\circ} \mathrm{C}\right)$ & 13.3 & 13.0 & 12.4 & 13.9 \\
Dissolved oxygen $(\mathrm{mg} / \mathrm{L})$ & 10.1 & 12.4 & 10.2 & 9.0 \\
$\mathrm{pH}$ & 7.4 & 7.0 & 7.0 & 7.9 \\
Salinity $(\% 0)$ & 0.0 & 23.0 & 0.3 & 23.0 \\
Conductivity $\left(\mu \mathrm{S} / \mathrm{cm}^{2}\right)$ & 120 & 29500 & 280 & 29500 \\
Alkalinity $\left(\mathrm{mg} \mathrm{CaCO}_{3} / \mathrm{L}\right)$ & 8.0 & 17.0 & 9.0 & 15.0 \\
Chlorophyll $a\left(\mathrm{mg} / \mathrm{m}^{3}\right)$ & 1.6 & 0.8 & 1.3 & 1.3 \\
\hline
\end{tabular}



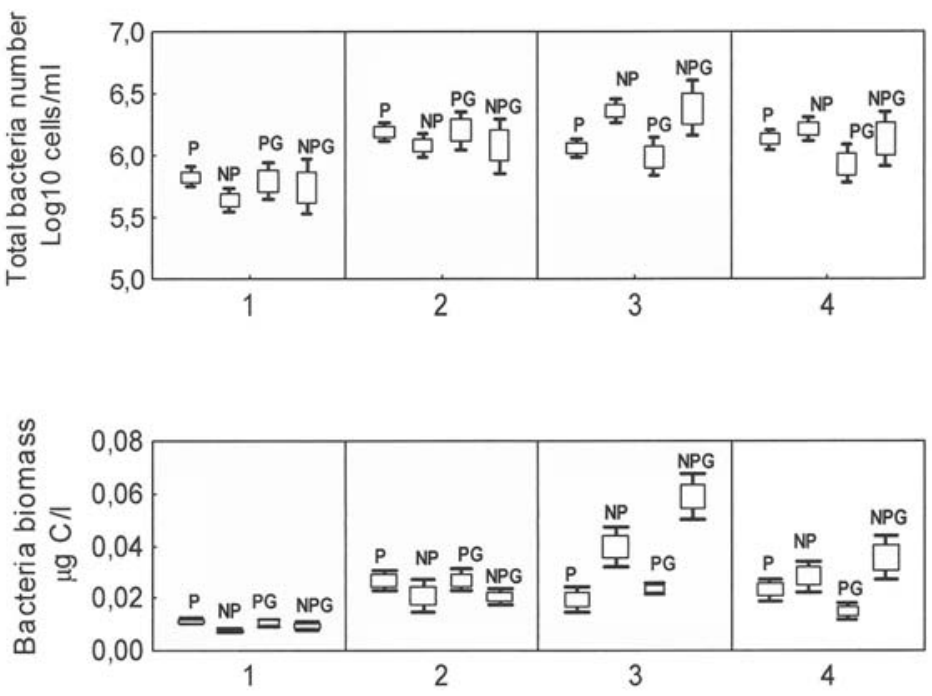

Days of incubation

Figure 3. Temporal variation of total bacterial number and biomass in the low tide experiment (Bar and whisker plot; bars: Mean \pm Standard error; whiskers: Mean \pm Standard Deviation; 20- $\mu$ m screened sample: P; 1- $\mu \mathrm{m}$ filtered sample: NP; $20-\mu \mathrm{m}$ screened sample with glucose amendment: PG; $1-\mu \mathrm{m}$ filtered sample with glucose amendment: NPG). Variación temporal del número total de bacterias y biomassa durante el experimento en baja marea (Barras y figura whisker; barras: Media \pm Error estándar,

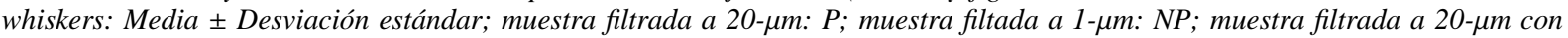
enriquecimiento de glucosa: PG; muestra filtrada a 1- $\mu$ m con enriquecimiento de glucosa: NPG).

the influence of the buffering capacity of seawater. The physical and chemical variables measured in the sampled area were similar to the values reported for the same area by Fidalgo (1998).

Total bacterial abundance appeared to be significantly higher at high tide $(p<0.01$, $t$-test) than at low tide (Fig. 2), since 9.18 $\times 10^{5} \pm 2.84 \times 10^{5}$ cells $/ \mathrm{ml}$, and $5.44 \times$ $10^{5} \pm 1.50 \times 10^{5}$ cells $/ \mathrm{ml}$, were respectively measured (mean \pm SD). By contrast, higher abundances of total coliforms, faecal coliforms, and faecal streptococci were recorded at low tide comparing to high tide ( $p<0.01, t$-test) (Fig. 2). In a 10-month study on the bacterioplankton of the Minho Estuary River (1996-1997), Pinheiro \& Fidalgo (2000) reported similar values for high tide water samples.

\section{Laboratory experiments}

\section{Low tide experiment}

Temporal variation of total bacterial number and biomass recorded in the low tide experiment is shown in figure 3. A steady increase of bacterial population abundance was recorded from the first to the second day of incubation, except for the samples with glucose amendment. Bacterial abundance did not seem to be controlled by the presence of predators (20 $\mu \mathrm{m}$-screened samples). Up to the second day of incubation, there was hardly any significant difference between screened and filtered samples. The difference only appeared in glucose-amended cultures, where a decrease in TBN was observed. At the end of the incubation period (fourth day), a similar decrease in TBN in the non-amended samples was observed.

A difference in the bacterial biomass between screened and filtered samples was observed after two days of incubation, with higher values in screened samples. However, this difference was maximal on the third day with the highest biomass values observed in filtered samples.

By comparing the total bacterial number and the biomass it was observed that in the screened samples (with and without glucose) the cell number increased while the bacterial biomass decrea- 


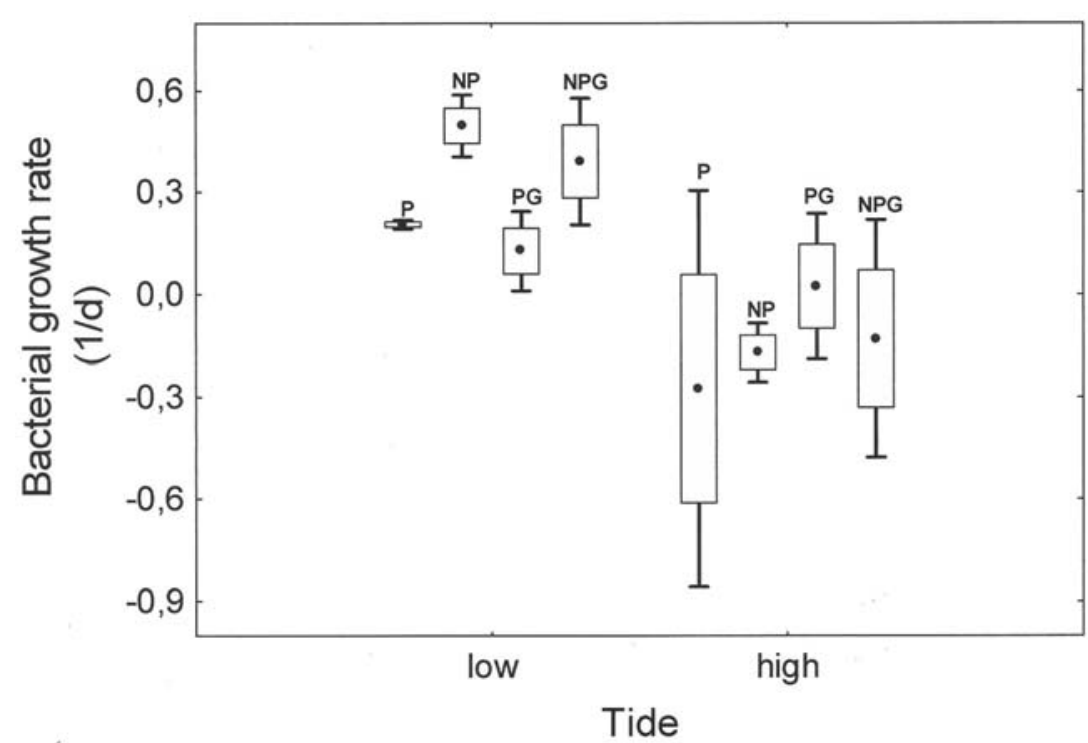

Figure 4. Mean bacterial growth rate in low and high tide experiments (Bar and whisker plot; bars: Mean \pm Standard error; whiskers: Mean \pm Standard Deviation; $20-\mu \mathrm{m}$ screened sample: P; $1-\mu \mathrm{m}$ filtered sample: NP; $20-\mu \mathrm{m}$ screened sample with glucose amendment: PG; $1-\mu \mathrm{m}$ filtered sample with glucose amendment: NPG). Tasa media de crecimiento en experimentos en baja y alta marea (Barra

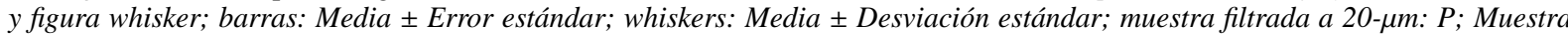

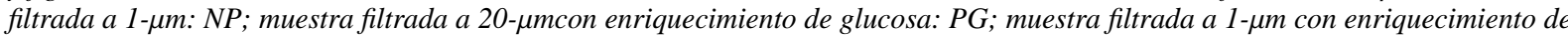
glucosa: $N P G$ )

sed. However, no decrease in biomass was observed in the filtered samples (with and without glucose). These findings are in accordance with growth rate calculations, because mean bacterial growth rates observed at low tide (Fig. 4) indicated significantly higher growth rates in filtered samples compared to screened ones. Thus, sample filtration seemed to have enhanced the growth rate in filtrates whose estimated values varied between 0.15 day $^{-1}$ and 0.50 day $^{-1}$.

\section{High tide experiment}

The temporal variation of total bacterial number and biomass in the high tide experiment is illustrated in figure 5. In contrast to the low tide experiment, bacterial abundance variation was not clearly related to the eventual absence or scarcity of predators in filtered samples.

Concerning biomass variation, an increase of bacterial biomass in screened samples was recorded after two days of incubation, as mentioned earlier for the low tide experiment. Generally, the community specific growth rates were higher in the $1 \mu \mathrm{m}$-filtered samples than in the $20 \mu \mathrm{m}$-filtered samples, except in one treatment during the high tide experiment (20 $\mu$ m-filtered samples without glucose) (Fig. 4). We do not know if this was a possible artefact, calling for a clarification in future experimentations.

In both experiments, the initial bacterial assemblages of incubated water samples that were filtered through $1 \mu \mathrm{m}$ to eliminate the predators contained less faecal indicator bacteria ( $p<0.01, t$-test) than in $20 \mu \mathrm{m}$-screened water samples. This may reflect the influence of the filtration step, which can considerably modify and affect the bacterial size distribution of the community, as reported by Suzuki (1999).

\section{DISCUSSION AND CONCLUSIONS}

The total bacterial abundance (TBN) values obtained were in the range reported for oligotrophic and mesotrophic coastal zones (Nybroe et al., 1992; Christoffersen et al., 1995; Suzuki, 

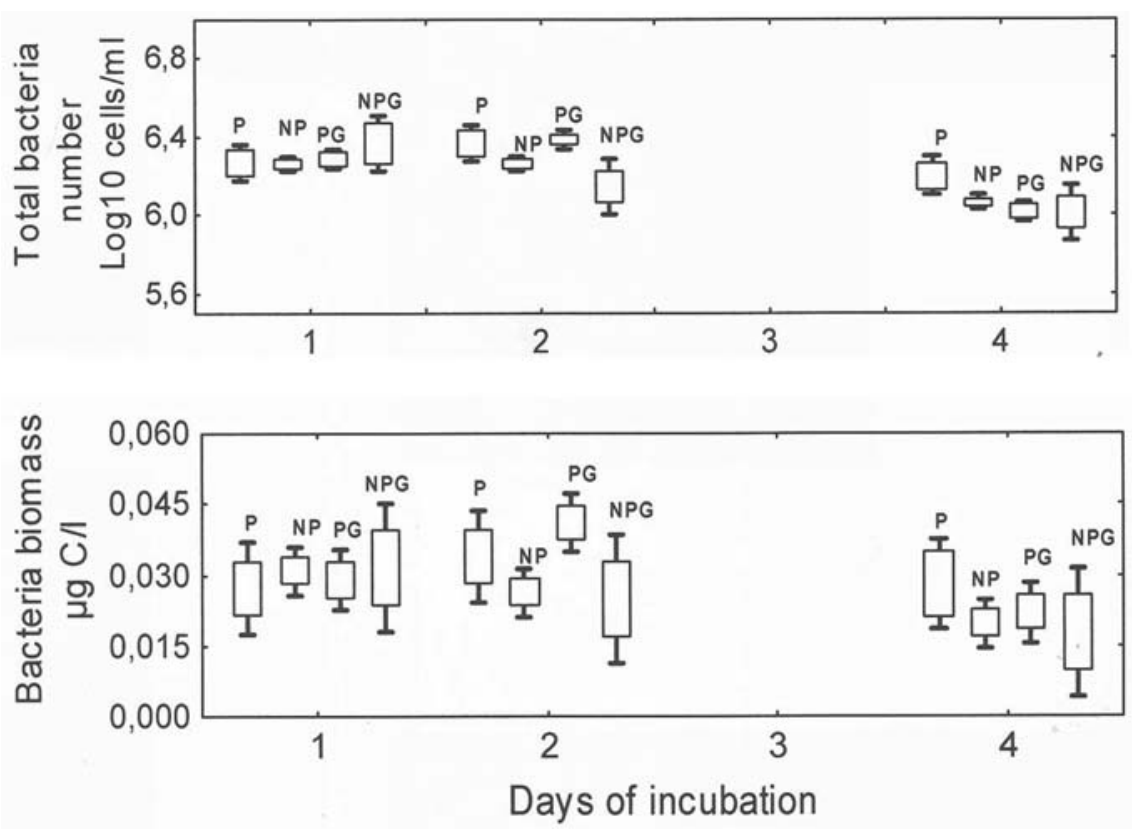

Figure 5. Temporal variation of total bacterial number and biomass in the high tide experiment (Bar and whisker plot; bars: Mean \pm Standard error; whiskers: Mean \pm Standard Deviation; $20-\mu \mathrm{m}$ screened sample: P; $1-\mu \mathrm{m}$ filtered sample: NP; $20-\mu \mathrm{m}$ screened sample with glucose amendment: PG; $1-\mu \mathrm{m}$ filtered sample with glucose amendment: NPG). Variación temporal del número y biomassa de total de bacterias en el experimento en condiciones de marea alta (Barras y figura whisker; barras: Media \pm error estándar;

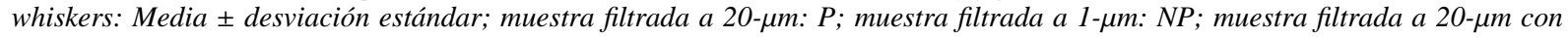
enriquecimiento de glucosa: PG; muestra filtrada a 1- $\mu$ m con enriquecimiento de glucosa: NPG).

1999). The higher TBN at high tide may be the result of several processes, such as a resuspension of bacteria from sediments by strong current movements within the prospected area. The higher occurrence of total coliforms, faecal coliforms, and faecal streptococci recorded at low tide may indicate the contribution of urban drainage and/or agricultural land run-off, as suggested by Fernández-Alvarez et al. (1991). However, the levels of faecal coliforms found in the Minho Estuary River indicated fairly clean waters, since the abundance of these indicators were within the range recommended by the Portuguese legislation for bathing purposes (Ministry of Environment of Portugal, 1998).

During this study, the obtained biomass values were in the range of those reported in the literature for different aquatic ecosystems (Azam et al., 1983; Linley et al., 1983; Gast, 1985; Mcmanus \& Fuhrman, 1988). Linley et al. (1983) reported a similar range for European coastal waters.
The incubation period used in these experiments (4 days) is generally considered to be adequate for bacterioplankton studies, because bacterial generation time has been reported to vary between 2 and 4 days (Vrede et al., 1999). Furthermore, 3-4 days is long enough for bacterioplankton to respond to nutrient manipulation (Pinhassi et al., 1999; Sherr et al., 1999; Vrede et al., 1999; Drakare, 2002).

Although it may be criticized, the volume incubated in this study was in the range of volumes generally used in this kind of experiments. In their interesting review, Duarte et al. (1997) came to the conclusion that, statistically, the median volume used in experiments with microbial aquatic ecology was about $800 \mathrm{ml}$.

Vrede et al. (1999) also reported that organic carbon concentrations as high as $18 \mathrm{mg} \mathrm{C} / \mathrm{L}$ (as glucose) had a positive effect on bacterial production but only a limited effect on bacterial abundance. A certain similarity can be found 
with our study, although we used a lower glucose concentration ( $1 \mathrm{mg} \mathrm{C/L})$. These observations are in agreement with Caron et al. (2000), who found no stimulatory or marginal effects of glucose amendment on bacterial production and growth in oligotrophic waters. Using the same range of glucose concentration to create a gradient of organic amendment $(0.3$ to $30 \mathrm{mg} \mathrm{C/L})$, Drakare (2002) compared competition ability between heterotrophic bacteria and picophytoplankton.

As described by Fidalgo (1998), the Minho Estuary River is an oligo-mesotrophic costal zone with low nutrient content $(\mathrm{P}$ and $\mathrm{N})$. This can indicate that the weak variation of bacterial abundance may be related to inorganic nutrient limitation. Thus, to enhance bacterial growth, the addition of these nutrients in the experimental design should have been considered, and it will be taken into account in future works.

Some of the smallest heterotrophic nanoflagellates may have been able to pass through $1 \mu \mathrm{m}$ pore size filters, and Mcmanus \& Fuhrman (1988) report evidence that up to $50 \%$ of the grazing activity (heterotrophic nanoflagellates) can pass $0.6 \mu \mathrm{m}$ pore-size filters. If this was the case, four days of incubation was enough time for nanoflagellates to increase in abundance and reduce bacterial biomass in the $1 \mu \mathrm{m}$ treatments of the high tide water experiment. This effect would be in accordance with Lebaron et al. (1999), who reported a rapid control of bacterioplankton biomass by protozoan grazing in batch mesocosms.

The delay of two days to increase biomass in screened samples in the high tide experiment could be the result of a "shift-up" in bacterial metabolic activity and a simultaneous lag-phase for protozoan predators before reaching sufficient density to allow them to control bacterial biomass in the subsequent days as observed by Sherr et al. (1999).

Comparing the experiments at both tidal conditions, it was clear that bacterial specific growth rates were significantly higher at low tide than at high tide. These differences can be compared to results reported by Schultz \& Ducklow (2000), who reported significant differences in patterns of bacterioplankton community metabolic capabilities along the salinity gradient of an estuary in Virginia. Cunha et al. $(2000,2001)$ found evidence of enhanced bacterial densities, glucose incorporation and biomass production in brackish water comparing with marine water in a Portuguese estuarine system; their findings can be compared to the tidal effects found in the present study and can help to explain why growth rates were much lower at high tide compared to the low tide experiment (Fig. 4).

These results seem to lead to a possible absence or decrease of grazing impact of predators in filtered samples. On the other hand, nutrient increase in filtrates via cell disruption can also favour bacterial growth (Ferguson et al., 1984; Sherr et al., 1999). Both effects could have also jointly resulted in the observed increase of the bacterial growth rate in our filtered samples.

Furthermore, the calculated bacterial specific growth rates in the Minho Estuary River were within the range reported by Mcmanus \& Fuhrman (1988) for marine waters; our results were, however, in the lower end of the range reported by Pulido-Villena \& Reche (2003) who stated values of bacterial specific growth rates that ranged from 0.26 to 3.34 day $^{-1}$ for a comprehensive range of aquatic ecosystems. Nonetheless, it must be emphasized that these authors referred to experimental situations without mineral nutrient limitation.

In conclusion, the physical and chemical conditions observed during the two tidal events of the Minho Estuary River can be considered as typical for oligo-mesotrophic costal zones. Although not expected, the bacterial abundance was higher during the high tide, probably due to hydrodynamics and resuspension of bacteria from the sediment. The abundance of faecal indicators was higher at low tide conditions, probably as a result of continental and agricultural land run-off influence.

Glucose amendment was not found to have a clear stimulating effect on bacterial growth in the described experiments with water samples from the oligo-mesotrophic waters of the Minho Estuary River. This result seems to indicate that the supplemented concentration may have been insufficient, and/or bacterioplankton growth may have been limited by inorganic nutrients. 
This study needs to be continued in order to better understand some fundamental aspects concerning interactions between bacteria and heterotrophic nanoflagellates in the studied estuary, by tackling in more detail the size and biomass distribution as well as growth rates of these two groups of micro-organisms.

\section{ACKNOWLEDGEMENTS}

This study was partially supported by CIIMAR (Centre for Marine and Environmental Research), and by a grant to Ibrahima Anne from the FCT-Foundation for Science and Technology (Grant: PRAXIS XXI/BD/13946/97).

\section{REFERENCES}

APHA. 1992. Standard Methods for the Examination of Water and Wastewater, $18^{\text {th }}$ ed. Washington DC, USA: American Public Health Association/American Water Works Association/Water Environment Federation.

AZAM, F., T. FENCHEL, J. G. FIELD, J. S. GRAY, L. A. MEYER-REIL \&. F. THINGSTAD. 1983. The ecological role of water-column microbes in the sea. Mar. Ecol. Prog. Ser., 10: 257-263.

AZEVEDO, M. F. 1995. Comparison of some bacterial organisms abundance in the water and in the bivalve mollusc Mytilus galloprovincialis Lamarck, from the Minho estuary River. M.Sc. thesis, University of Porto. $63 \mathrm{pp}$ (in Portuguese).

CALBET, A., M. L. LANDRY \& S. NUNNERY. 2001. Bacteria-flagellate interactions in the microbial food web of the oligotrophic subtropical North Pacific. Aquat. Microb. Ecol., 23: 283-292.

CARON, D. A., E. L. LIM, R. W. SANDERS, M. R. DENNET \& U-G. BERNINGER. 2000. Response of bacterioplankton and phytoplankton to organic and inorganic nutrient additions in contrasting oceanic ecosystems. Aquat. Microb. Ecol., 22: 175-184.

CHRISTOFFERSEN, K., T. AHL \& O. NYBROE. 1995. Grazing of nonindigenous bacteria by nanosized protozoa in a natural coastal system. Microb. Ecol., 30: 67-78.

CUNHA, M. A., M. A. ALMEIDA \& F. ALCÂNTARA. 2000. Patterns of ectoenzymatic and heterotrophic activities along a salinity gradient in a shallow tidal estuary. Mar. Ecol. Prog. Ser., 204: $1-12$.

CUNHA, M. A., M. A. ALMEIDA \& F. ALCÂNTARA. 2001. Short-term responses of the natural planktonic bacterial community to the changing water properties in an estuarine environment: ectoenzymatic activity, glucose incorporation, and biomass production. Microb. Ecol., 42: 69-79.

DRAKARE, S. 2002. Competition between picoplanktonic cyanobacteria and heterotrophic bacteria along crossed gradients of glucose and phosphate. Microb. Ecol., 44: 327-335.

DUARTE, C. M., J. M. GASOL \& D. VAQUÉ. 1997. Role of experimental approaches in marine microbial ecology. Aquat. Microb. Ecol., 13: 101111.

FATTAL, B., E. PELEG-OLEVSKY, Y. YOSHPEPURER \& H. I. SHUVAL. 1986. The association between morbidity among bathers and microbial quality of seawater. Wat. Sci. Techn., 18: 59-69.

FERGUSON, R. L., E. N. BUCKLEY \& A. V. PALUMBO. 1984. Response of marine bacterioplankton to differential filtration and confinement. Appl. Environ. Microbiol., 47: 49-55.

FERNÁNDEZ-ALVAREZ, R. M., S. CARBALLOCUERVO, M. C. DE LA ROSA-JORGE \& J. RODRIGUEZ-DE LECEA. 1991. The influence of agricultural run-off on bacterial populations in a river. J. Appl. Bacteriol., 70: 437-442.

FIDALGO, M. L. 1998. Contribution to the ecological characterisation of the river Minho estuary (Northern Portugal). Verh. Internat. Verein. Limnol., 26: 1448-1451.

FOWLER, J., L. COHEN \& P. JARVIS. 1998. Practical statistics for field biology, $2^{\text {nd }}$ ed. New York: John Wiley \& Sons. 259 pp.

GAST, V. 1985. Bacteria as a food source for microzooplankton in the Schlei Fjord and Baltic Sea with special reference to ciliates. Mar. Ecol. Prog. Ser, 22: 107-120.

GOLTERMAN, H. L., R. S. CLYMO \& M. A. M. OHNSTAD. 1978. Methods for physical and chemical analysis of fresh waters, IBP Handbook no $8,2^{\text {nd }}$ ed. Oxford, London, Edinburgh, Melbourne: Blackwell Scientific Publications. 213 pp.

HANSEN, B. \& K. CHRISTOFFERSEN. 1995. Specific growth rates of heterotrophic plankton organisms in a eutrophic lake during a spring bloom. $J$. Plankton Res., 17: 413-430. 
LEBARON, P., P. SERVAIS, M. TROUSSELLIER, C. COURTIES, J. VIVES-REGO, G. MUYZER, L. BERNARD, T. GUINDULAIN, H. SCHÄFER \& E. STACKEBRANDT. 1999. Changes in bacterial community structure in seawater mesocosms differing in their nutrient status. Aquat. Microb. Ecol., 19: 255-267.

LINLEY, E. A. S., R. C. NEWELL \& M. I. LUCAS. 1983. Quantitative relationships between phytoplankton, bacteria and heterotrophic microflagellates in shelf waters. Mar. Ecol. Prog. Ser, 12: 77-89.

LORENZEN, C. J. 1967. Determination of chlorophyll and phaeopigments: spectrophotometric equations. Limnol. Oceanogr., 12: 343-346.

MARSALEK, J., B. J. DUTKA \& I. K. TSANIS. 1994. Urban impacts on microbiological pollution of the St Clair river in Sarnia, Ontario. Wat. Sci. Tech., 30 (1): 177-184.

MCMANUS, G. B. 1993. Growth rates of natural populations of heterotrophic nanoplankton. In: Handbook of methods in aquatic microbial ecology. Kemp P., Sherr, B., Sherr E. \& Cole J. (eds.): 557-562. Lewis Publishers, Boca Raton.

MCMANUS, G. B. \& J. A. FUHRMAN. 1988. Control of marine bacterioplankton populations: measurement and significance of grazing. Hydrobiologia, 159: 51-62.

MINISTRY OF ENVIRONMENT OF PORTUGAL. 1998. Law no 236/98 of 1st of August. Diário da República, I Série-A, 176: 3676-3718. (in Portuguese).

NORLAND, S. 1993. The relationship between biomass and volume of bacteria. In: Handbook of methods in microbial ecology. Kemp P., Sherr, B., Sherr E. \& Cole J. (eds): 303-307. Lewis Publishers, Boca Raton.

NYBROE, O., K. CHRISTOFFERSEN \& B. RIEMANN. 1992. Survival of Bacillus licheniformis in seawater model ecosystems. Appl. Environ. Microbiol., 58: 252-259.
PINHASSI, J., F. AZAM, J. HEMPḦ̈LÄ, R. A. LONG, J. MARTINEZ, U. L. ZWEIFEL \& A. HAGSTRÖM. 1999. Coupling between bacterioplankton species composition, population dynamics, and organic matter degradation. Aquat. Microb. Ecol., 17: 13-26.

PINHEIRO, A. \& M. L. FIDALGO. 2000. Contribution for the study of bacterioplankton of the river Minho estuary (Portugal). Verh. Internat. Verein. Limnol., 27: 1890-1893.

PORTER, K. G. \& Y. S. FEIG. 1980. The use of DAPI for identifying and counting aquatic microflora. Limnol. Oceanogr., 25: 943-948.

PULIDO-VILLENA, E. \& I. RECHE. 2003. Exploring bacterioplankton growth and protein synthesis to determine conversion factors across a gradient of dissolved organic matter. Microb. Ecol., 46: 33 42.

SCHULTZ, G. E. \& H. DUCKLOW. 2000. Changes in bacterioplankton metabolic capabilities along a salinity gradient in the York river Estuary, Virginia, USA. Aquat. Microb. Ecol., 22: 163-174.

SHERR, B. F., E. B. SHERR \& C. PEDRÓS-ALIÓ. 1989. Simultaneous measurement of bacterioplankton production and protozoan bacterivory in estuarine water. Mar. Ecol. Prog. Ser., 54: 209-219.

SHERR, E. B., B. F. SHERR \& C. T. SIGMON. 1999. Activity of marine bacteria under incubated and in situ conditions. Aquat. Microb. Ecol., 20: 213- 223.

SUZUKI, M. 1999. Effect of protistan bacterivory on coastal bacterioplankton diversity. Aquat. Microb. Ecol., 20: 261-272.

USEPA. 1986. Ambient water quality criteria for bacteria. Washington, DC 20460. EPA 440/5-84002.

VREDE, K., T. VREDE, A. ISAKSSON \& A. KARLSSON. 1999. Effects of nutrients (phosphorus, nitrogen and carbon) and zooplankton on bacterioplankton and phytoplankton-a seasonal study. Limnol. Oceanogr., 44: 1616-1624. 